\title{
Isolation and Identification of Some Pathogenic Fungi from Selected Infected Vegetable Plants in Kushtia Local Area, Bangladesh.
}

\author{
AUTHORS: Md. Al-Amin Milon ${ }^{1}$, Dr. Md. Rezuanul Islam* \\ AFFILIATIONS: \\ 1 Department of Biotechnology and Genetic Engineering, Faculty of Biological Sciences, \\ Islamic University, Kushtia-7003, Bangladesh. \\ *Address correspondence to: rezwaniu@gmail.com
}

\begin{abstract}
The aim of this study is to isolate the pathogenic fungi from selected infected vegetable plants in the local area of kushtia, Bangladesh. Some of the most devastating and harmful pathogenic fungi are Phytopthora infestans and Aspergillus niger which we were isolated from edible vegetables potato and onion respectively by using Potato dextrose agar (PDA) using morphological and fungal characteristics. After morphological study, we observe that Phytopthora infestans has Sporangia shape spores with white color colony and Aspergillus niger has produced black colonies with wooly smooth-walled colonies of conidia. Those fungi creates tremendous yield lose subsequently decrease the market value and nutritional value of vegetables. This observed characteristics have similarity with the previous research of another Scientists. But further study is needed to confirm our identified isolates. Because of Covid-19 pandemic, we are unable to study more in laboratory.
\end{abstract}




\section{CHAPTER I}

INTRODUCTION 


\section{Introduction}

\subsection{Background}

Generally, vegetables are considered as the leafy outgrowth of plants or plants shoot used for food. These include those plants or plant part used in making soup or served as an integral part of main meal (Wu, C. 2016). Vegetables can also be regarded as the component of plants, such components includes leaves, stalk, roots, tubers, bulbs, flowers and seed (ICMSF 1998). Vegetables are important protective food and highly beneficial for the maintenance of health and prevention of diseases. They contain valuable food ingredients which are essential for the proper function of the body. Vegetable contain various medicinal and the therapeutic agents and are valued mainly for their high vitamin and mineral content. Studies have evaluated the association of fruit and vegetables consumption with the reduction of risk of many diseases (Salvin, S. 2013). The incidence of microorganisms in vegetables maybe expected to reflect the sanitary quality of the processing steps and the microbiological condition of the raw product at the time of processing (Nguyen, C. 1994). However, pathogenic microorganism may be present in minimally processed vegetables as the minimal technological processing may be unable to remove the original contamination resulting from air, soil, water, insects, animals, workers, harvesting and transporting equipment. Certain fungi such as Aspergillus, Fusarium, and Penicillium spp. grow on vegetables and their growth may result in production of toxins known as mycotoxins (such as alkaloids and polyketones that are toxic to animals including humans), which can cause a variety of ill effect in human from allergic responses to immune suppression and cancer (Pitt, H. 1997). Microorganisms have undoubtedly resulted in increased numbers of documented outbreaks. The risk of illness associated with raw vegetable products can be reduced by removing or killing pathogenic microorganisms by washing or treating them with sanitizers. However, the hydrophobic cutin, diverse surface morphologies and abrasions in the epidermis of fruit and vegetables limits the efficacy of this treatment (Burnett, B. 2001). Vegetables are frequently consumed raw without being exposed to the processes that reliable eliminates pathogens. Washing fruits and vegetables in chlorinated water can reduce fungal levels but cannot be relied upon to eliminate pathogens. Eating or drinking contaminated foods or drinks can cause food borne disease (Adebayo, K. 2012). Many different types of bacteria, viruses and

parasites can contaminate food, so there is numerous different food borne infections. The consumption of carrot, cucumber, onion and cabbage in Nigeria has increased tremendously in 
recent years due increased awareness on their health important. Carrot is known to contain an important biologically active compound, carotenoid (Asagbra, O. 2002). It has been estimated that $20 \%$ of vegetables harvested for human consumption are lost through microbial spoilage. The primary causative agents of microbial spoilage are bacteria, yeasts and mold (Jay, N. 2005). Spoilage microorganisms can be introduced to the crop on the seed itself, during crop growth in the field, during harvesting and post-harvest handling or during storage and distribution (Barth, K. 2009). The same types of soil borne spoilage microbes that occur on produce are the same spoilage microorganisms that are present on harvesting equipment, handling equipment, in the packing house, in the storage facility and on food contact surfaces throughout the distribution chain (Barth, K. 2009). Fungi cause spoilage of many vegetables and crops. They lead to the destruction of plants quality and reduce the yield of crops. Several times, our vegetables are being spoiled by fungi which lead to decreases in the productivity of the vegetables. This research work is initiated to isolate and identify fungi that spoils these vegetables in order to find a necessary means to prevent and control the spoilage of these vegetables and which will exert a tremendous effect in the socio-economic status of the people. Our effort had the isolation of Rhizosphere soil bacteria and observation of those bacterial anti-fungal activity, but it was not possible for pandemic situation.

\subsection{Vegetables}

Vegetables are vital sources of nutrient to human beings. They are the fresh and edible portions of herbaceous plants. They are important food and highly beneficial for the maintenance of health and prevention of diseases. They are valued mainly for their high carbohydrate, vitamin and mineral contents. There are different kinds of vegetables; they may be edible roots, stems, leaves, fruits or seeds. Each group contributes to diet in its own way (Hanif, J. 2006).Vegetables are increasingly recognized as essential for food and nutrition security. Vegetable production provides a promising economic opportunity for reducing rural poverty and unemployment in developing countries and is a key component of farm diversification strategies. Vegetables are mankind's most affordable source of vitamins and minerals needed for good health. 


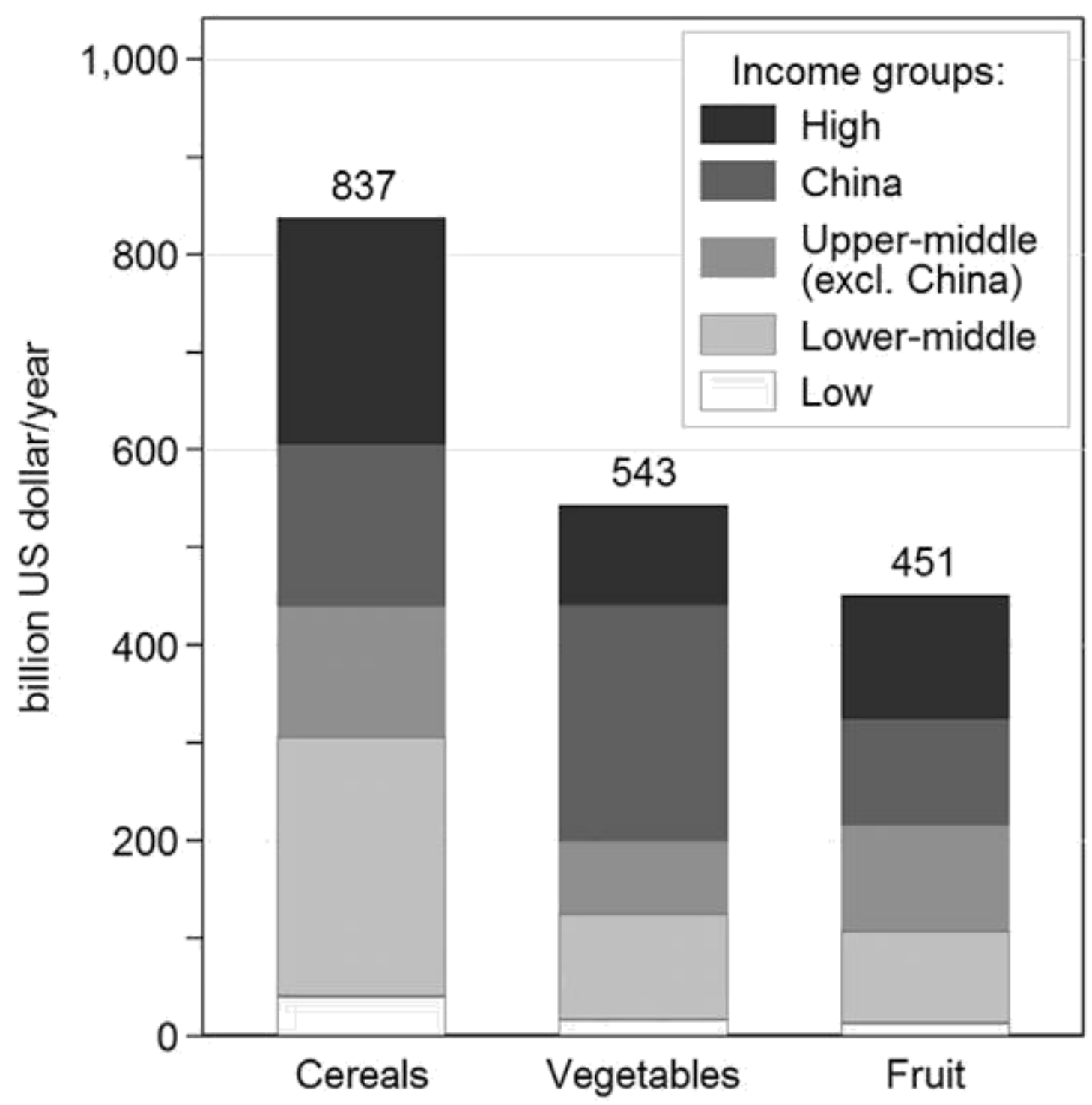

Figure-1: Farmgate value of the global production of food cereals, vegetables and fruit, average 2012-2013, by national income categories, current US dollars. Source: FAO (2017): Database on the value of agricultural production. Notes: World Bank 2016 classification used to group countries. FAO data on Gross Production Value (current million US\$) are incomplete. Missing values were imputed using linear regression models for each crop using the Gross Production Value (constant 2004-2006 1000 I\$) as predictor, which is more complete. Feed maize excluded from cereals. Watermelons, melons and avocados classified as fruit. 


\subsubsection{Nutrients in some wild fruits and vegetables and their role in human physiology and health}

\subsubsection{Vitamin C (Vitamin C)}

Vitamin $\mathrm{C}$, also known as ascorbic acid is an important water soluble vitamin that plays an important role in human physiology although the body cannot synthesis it and therefore must be introduced exogenously (Rivas, K. 1997). Among other functions, this nutrient is essential for collagen synthesis and this includes structures such as gums, bones as well as binding materials in skin muscle or scar tissue. The proper functioning of the immune system is also widely linked to Vitamin $\mathrm{C}$ and when it is insufficient in the diet, humans suffer from scurvy. This nutrient which is heat labile is widely distributed in fresh fruits, especially citrus and vegetables (Iqbal, H. 2004).

\subsubsection{Dietary fiber}

Although dietary fiber (roughage) has many diverse definitions around the world, the Institute of Medicine defined dietary fiber as consisting of indigestible carbohydrates and lignin that is intrinsic and intact in plants (Slavin, A. 2013). Specifically, besides the well-known role of fiber in improving the digestive system, dietary fiber in general disease prevention (Burkitt, R. 1972), prevention of cancer (Bingham, H. 2003), in the management of diabetes (Jenkins, T. 1978) and its mechanism of action in the human colon (Cummings, L. 1978) have been reported. Known high fiber foods include whole grains, fruits, vegetables and legumes.

\subsubsection{Protein}

Protein functions include their role as enzymes, transport carriers, in membranes and as hormones (DRI, 2006). Also, perhaps the most important aspect of proteins is their amino acid compositions which are required for the synthesis of body protein and other nitrogen-containing compounds ( $\mathrm{Wu}, \mathrm{C}$. 2016). Although, the nine indispensable amino acids are mainly found in animal sources such as meat, cheese, poultry, eggs and yogurt, those from plant products tend to be deficient in one or more (DRI, 2006). Increased dietary protein intake as a weight reduction intervention has been widely reported since variations of these diets were first proposed in the 1960s (Jeor, D. 2001), however, these have been questioned and thought to actually promote renal damage among other conditions (Martin, L. 2005). Further studies are required to support these studies. Notwithstanding this, perhaps the advantage of plant products would be their ability to provide other nutrients such as minerals and vitamins. 


\subsubsection{Calcium $(\mathrm{Ca})$}

Besides its important and widely known role in structure and function of bones, Ca regulates intracellular events in body tissues and plays an important role in muscle contraction, enzyme activities, nerve functions, blood clotting and regulation of homeostasis among other functions (Adamasca, B. 2014). Although the major sources of $\mathrm{Ca}$ are milk and dairy products, their insufficient consumption especially in poor third world countries is a cause for concern (Adamasca, B. 2014). Insufficient $\mathrm{Ca}$ in the diet has been linked to osteoporosis and bone fractures in adults (Whiting, 2010), softening and deformation of the bones (rachitis) in children normally under two years of age (Adamasca, B. 2014) as well as ageing and cardiovascular diseases (Beto, G. 2015).

\subsubsection{Iron $(\mathrm{Fe})$}

Iron has for long been recognized for its role in maintaining a healthy immune system and disease prevention and aiding in energy production (Beard and Dawson, 1997). There are two types of Fe, viz, Heme iron which is derived from animal foods and plant tissues and Non-heme iron which is derived only from plant tissues (Hurrell, E. 2010). Furthermore, close to $90 \%$ of Fe needed on a daily basis is obtained from the breakdown of circulating red blood cells. Due to Fe losses experienced by different individuals in different age groups on a daily basis, for example the skin, intestines, urinary tract and menstrual losses in women, iron must be provided in the diet in order to maintain the Fe balance needed in the body. In general, heme iron absorption is about 25\% and that of non-heme is less than 5\% (Monsen, J. 1999). Non heme Fe absorption depends on the Fe status of the individual as well as the balance between absorption inhibitors and enhancers.

\subsubsection{Magnesium (Mg)}

Magnesium is vital in human nutrition due to its function as a cofactor for more than 300 essential enzyme systems, its requirement for increased DNA and RNA synthesis, energy generation as well as glycol sis and has also been shown to be essential for mitochondria to carry out oxidative phosphorylation (Food and Nutrition Board, 1997). Mg deficiency has also been associated with insulin resistance and vascular disease (Nadler, S. 1993). Evidence suggests that the majority of $\mathrm{Mg}$ deficiency diseases are due to non-consumption of fresh, green vegetables 


\subsubsection{Vegetables in the global food economy}

Few people appreciate the significant economic role already played by vegetables and their close cousins, fruits. Global fruit and vegetable production, at nearly $\$ 1$ trillion per year, exceeds the farmgate value of all food grains combined (US\$ 837 billion). This section provides more disaggregation of trends relevant to vegetables. Substantial rises in both production and consumption are occurring in middle-income countries, but not in low-income countries. There are indications of underinvestment in vegetable research, especially by the public sector and in improving "indigenous" or "traditional" vegetables that primarily reach local and regional markets. The most dominant vegetables in the global food economy are tomatoes, cucurbits (pumpkins, squashes, cucumbers, and gherkins), alliums (onions, shallots, garlic) and chilies. These vegetables are consumed in nearly all countries - although with much variation in shapes, sizes, colors and tastes — and are rightly called "global."

While the marketing of global vegetables accounts for significant revenue streams, traditional vegetables often have superior nutritional properties (Yang, K. 2009). For instance, $100 \mathrm{~g}$ of leaves of amaranth, jute mallow, African nightshade or vegetable cowpea can provide over $100 \%$ of the vitamin A needs of pregnant women (World Vegetable Center, 2017).Tomatoes alone are the fourth most economically-valuable food crop produced in low- and middle-income countries, after rice, sugarcane and wheat. Tomatoes accounted for US\$ 63 billion per year in traded value (at farmgate) in 2012-13, with 35\% of this value produced in China. The rapid growth in tomato production in middle-income countries since 1990, with the remarkable six-fold increase in per capita tomato production in China reflecting the country's overall growth in horticultural production and the potential for economic gain associated with tomatoes. These opportunities are foregone in low-income countries as the trend line for tomato production in these countries is nearly flat. Rising vegetable demand is driven by rising incomes as well as population growth. Globally, a $1 \%$ increase in per capita income in developing countries is associated with a $0.5 \%$ increase in per capita vegetable availability. It follows that the bulk of the global supply of fruit and vegetables ( $77 \%$ of total value) is produced in populous middle-income countries. China accounts for $45 \%$ of the global value of vegetable production and $24 \%$ of fruit production (FAO, 2017). India comes second, accounting for $8 \%$ and $7 \%$ of global vegetable and fruit production, respectively.FAO data on food balance sheets suggest that the current per capita availability of vegetables in upper-middle income countries has converged to levels observed in high-income 
countries and that availability in middle income countries is increasing at the same rate. Middleincome countries, on average, now produce a large enough quantity of fruit and vegetables to meet the FAO/WHO recommended intake levels of $200 \mathrm{~g}$ of fruit and $200 \mathrm{~g}$ of vegetables per day (WHO/FAO, 2003). Low-income countries, on the other hand, have seen little growth in their average vegetable production, and availability is well below the recommended consumption level, although this may be partly compensated by production and consumption of more traditional vegetables, not captured in the FAO data.6It is also likely that productivity of vegetable farming is not raising as rapidly as it could be. Technological progress relies upon systematic research efforts to develop new varieties, crop management techniques, And innovations in postharvest handling and processing. Even in high income countries like the United States, there is evidence that public funding for vegetable research (as part of the "specialty crops" sector) is lower than expected given its economic value and its contribution to human health (Alston, P. 2008). Public funding for research in low- and middle-income countries is rarely disaggregated enough to assess investments in vegetable research alone (Alston, $\mathrm{P}$. 2008).

The statistics of the Food and Agriculture Organization of the United Nations (FAO) cover 25 primary vegetable products (http://www.fao.org/faostat/en/\#data/QC). Global primary vegetable production reached 1.09 billion tons in 2018, about $37 \%$ of global cereal production (2.96 billion tons) [42]. Asia is by far the largest producer of primary vegetables, responsible for threequarters of global production. During the past 10 years (2008-2018), there was a $24 \%$ increase in global commercial vegetable production, mainly attributable to a significant production increase in Africa (32\%) and Asia (28.3\%). The estimated farmgate value of annual global vegetable production reached 543 billion United States dollars (US\$) in 2012-2013, about 65\% of all food cereals combined, estimated at 837 billion US\$ [37]. 


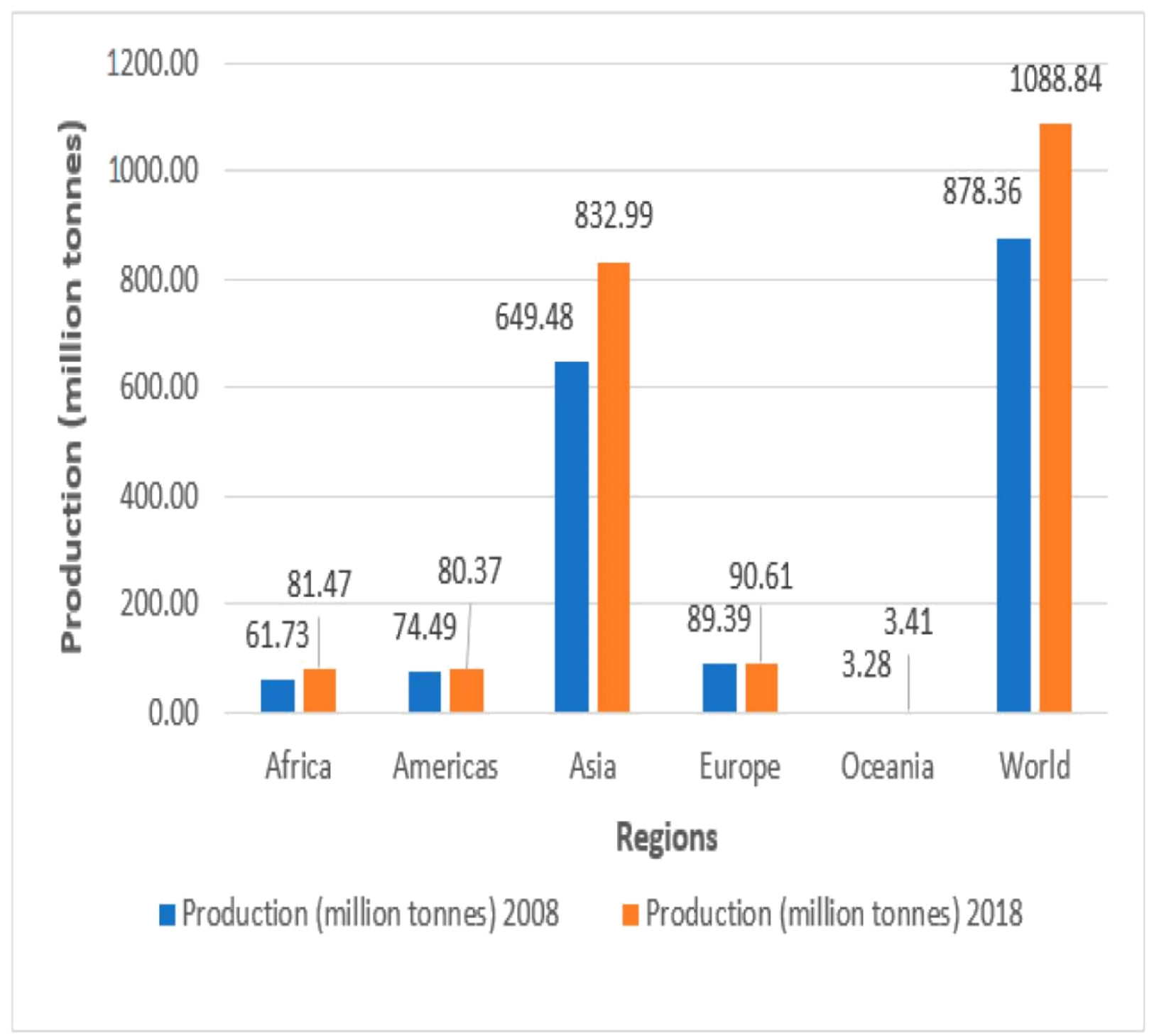

Figure-2: Comparison of global production of primary vegetables in 2008 and 2018, by major regions (Source: Statistics Division of FAO) 


\subsection{Fungi}

In the past few years, fungal diseases caused estimated over 1.6 million deaths annually and over one billion people suffer from severe fungal diseases (Brown, A. 2012). Public health surveillance of fungal diseases is generally not compulsory, suggesting that most estimates are conservative (Casadeval, 1. 2017). Fungal disease can also damage plants and crops, causing major losses in agricultural activities and food production (Savary, R. 2012). Animal pathogenic fungi are threatening bats, amphibians and reptiles with extinction (Casadeval, 1. 2017). It is estimated that fungi are the highest threat for animal-host and plant-host species, representing the major cause (approximately 65\%) of pathogen-driven host loss (Fisher, M. 2012). In this complex scenario, it is now clear that the global warming and accompanying climate changes have resulted in increased incidence of many fungal diseases (Garcia, S. 2010). On the basis of all these factors, concerns on the occurrence of a pandemic of fungal origin in a near future have been raised (Casadeval, 1. 2017). In this context, to stop forgetting and underestimating fungal diseases is mandatory.

Most phytopathogenic fungi belong to the Ascomycetes and the Basidiomycetes. The fungi reproduce both sexually and asexually via the production of spores and other structures. Spores may be spread long distances by air or water, or they may be soil borne. Many soil inhabiting fungi are capable of living saprotrophically, carrying out the part of their life cycle in the soil. These are facultative saprotrophs (Compaore, F. 2011).Fungal diseases may be controlled through the use of fungicides and other agriculture practices. However, new races of fungi often evolve that are resistant to various fungicides. Biotrophic fungal pathogens colonize living plant tissue and obtain nutrients from living host cells. Necrotrophic fungal pathogens infect and kill host tissue and extract nutrients from the dead host cells.

\subsubsection{Ascomycetes}

Ascomycota is a phylum of the kingdom Fungi that, together with the Basidiomycota, forms the subkingdom Dikarya. Its members are commonly known as the sac fungi or ascomycetes. It is the largest phylum of Fungi, with over 64,000 species. The defining feature of this fungal group is the "ascus" meaning "sac" or "wineskin", a microscopic sexual structure in which nonmotile spores, called ascospores, are formed. However, some species of the Ascomycota are asexual, meaning that they do not have a sexual cycle and thus do not form asci or ascospores (Jensen, A. 2013). Familiar examples of sac fungi include morels, truffles, brewer's 
yeast and baker's yeast, dead man's fingers, and cup fungi. The fungal symbionts in the majority of lichens (loosely termed "ascolichens") such as Cladonia belong to the Ascomycota.

Fusarium spp. (Fusarium wilt disease)

Thielaviopsis spp. (canker rot, black root rot, Thielaviopsis root rot)

Verticillium spp.

Magnaporthe grisea (rice blast)

Sclerotinia sclerotiorum (cottony rot)

\subsubsection{Basidiomycetes}

Basidiomycota is one of two large divisions that, together with the Ascomycota, constitute the subkingdom Dikarya (often referred to as the "higher fungi") within the kingdom Fungi. More specifically, Basidiomycota includes these groups: mushrooms, puffballs, stinkhorns, bracket fungi, other polypores, jelly fungi, boletes, chanterelles, earth stars, smuts, bunts, rusts, mirror yeasts, and the human pathogenic yeast Cryptococcus. Basidiomycota are filamentous fungi composed of hyphae (except for basidiomycota-yeast) and reproduce sexually via the formation of specialized club-shaped end cells called basidia that normally bear external meiospores (usually four). These specialized spores are called basidiospores. However, some Basidiomycota are obligate asexual reproducers (Borth, M. 2009). Basidiomycota that reproduce asexually (discussed below) can typically be recognized as members of this division by gross similarity to others, by the formation of a distinctive anatomical feature (the clamp connection), cell wall components, and definitively by phylogenetic molecular analysis of DNA sequence data.

Ustilago spp. (smuts) smut of barley

Rhizoctonia spp.

Phakospora pachyrhizi (soybean rust)

Puccinia spp. (severe rusts of cereals and grasses)

Armillaria spp. (honey fungus species, virulent pathogens of trees)

\subsubsection{The Impact of Fungal Infections on Food Crops and Disproportionate Impact in Developing Countries}

Fungal diseases in developing countries demand special attention. Many of the fungal diseases in Latin America are often overlooked, although they clearly fulfil the criteria to be classified as neglected human diseases (Rodrigues, P. 2016). The general impact of fungal pathogens on 
human health goes beyond the ability of fungi to infect humans, since they destroy a third of all food crops annually (Fisher, R. 2012), causing economical loss and impacting global poverty. Statistics from the 2009-2010 world harvest (www.fao.org or FAOSTAT1) suggest fungiinduced losses in five of the most important crops globally (rice, wheat, maize, potatoes, and soybean). If those losses were mitigated, these crops would have been enough to feed $8.5 \%$ of the seven billion populations in 2011 (Fisher, R. 2012). Furthermore, in a hypothetical event where these five crops were affected simultaneously, approximately $61 \%$ of the world's population would not have food (Fisher, R. 2012). The most economically devastating fungi are Magnaporthe Oryza, affecting rice and wheat, followed by Botrytis cinerea, which has a broad host range and Puccinia spp., affecting wheat (Dean, V. 2012). Several high-value crops produced in the tropics, such as bananas, coffee, cacao, spices, mangos, and several nuts, are currently affected by fungal infections and these crops are not produced colder climates (Drenth, G. 2016). Therefore dependence of crop produced in tropical regions aggravated with a lack of biodefense and preparedness might result in disastrous economic consequences worldwide.

Fungal infections of invertebrate hosts may also impact agricultural crises due to ecological imbalance. For instance, bee broods are susceptible to fungal infections caused by genera of Ascosphaera and Aspergillus (Jensen, R. 2013), and the agricultural production worldwide is highly dependent on pollination mediated by bees (Aizen, N. 2009). Fungal infection of bees may precipitate a disaster (Bromen, S. 2010), with unpreceded impact on agriculture and various plant species.

Although weeds are the major cause of crop loss on a global scale, major losses are suffered by agricultural crops due to insect damage and plant diseases. In rounded (approximate) figures, the world-wide annual production tonnage \%age lost to various pests at the start of the 21 st century have been estimated as follows: losses due to animal pests, 18\%;microbial diseases, $16 \%$ (and $70-80 \%$ of these losses were caused by fungi);weeds, $34 \%$; making a grand total of $68 \%$ average annual loss of crop production tonnage (Oerke, K. 2006). Of course, it is not only fungi that cause plant disease. There are bacteria, viruses, nematode worms (eel worms), aphids and insects as well as fungi. Serious plant diseases are caused by all these other pests, but fungi probably cause the most severe losses due to disease around the world. For one thing there are more plant pathogenic fungi than there are plant pathogenic bacteria or viruses. One survey made several 
years ago in the American State of Ohio came up with the estimate that the State had one thousand diseases of plants caused by fungi, one hundred caused by viruses and fifty due to bacteria. Crop protection measures include weed control, which can be managed mechanically or chemically, and the control of animal pests or diseases, which relies heavily on synthetic chemicals (Jinazali, N. 2017). Pesticide use has enabled farmers to modify production systems to increase crop productivity while still maintaining some measure of control over the damaging effect of pests. Unfortunately, despite large increases in pesticide use, crop losses have not significantly decreased during the last 40 years.

Crop losses are caused by both biological and physical aspects of the environment that lead to a lower actual yield than the site can be expected to attain. The attainable yield is the realistic technical maximum under the best achievable growth conditions. It is generally much less than the yield potential, which is the theoretical maximum that cannot be reached under practical growth conditions in the field. Crop losses are best expressed as a proportion of attainable yield but sometimes the proportion of the actual yield is calculated. Pests reduce crop productivity in various ways, for example by: reducing the stand (that is, the population) of plants (pathogens that kill the host, like damping-off pathogens that kill seedlings, are examples)reducing photosynthetic rate (fungal, bacterial, virus diseases);accelerating plant senescence (most pathogens);shading and 'stealing' light (weeds, some pathogens);depleting assimilate (nematodes, pathogens, sucking arthropods);consuming tissue (chewing animals, necrotrophic pathogens); competition for inorganic nutrients (weeds).Crop losses can be quantitative and/or qualitative, and expressed in absolute terms ( $\mathrm{kg}$ ha-1, or financial loss ha-1, for example) or in relative terms ( $\%$ loss in production tonnage, for example):quantitative losses result from reduced productivity giving a lesser yield per unit area; qualitative losses from pests can result from: reduced content of a normal ingredient(s) of the crop, reduced market quality (for example miss-shaped, blemished fruit and vegetables),reduced storage quality, contamination of the harvested product with pests, parts of pests or toxic products of the pests (for example, mycotoxins).

Biological and physical aspects of the environment that lead to a lower crop yield. Biological and physical aspects of the environment that lead to a lower actual yield than the site can be expected to attain under ideal circumstances (Oerke, K. 2006).Agricultural survey statistics make it clear 
that crop losses directly attributable to fungi are very considerable. Of course, it's changing all the time because, at least in part, losses depend on the weather, but it appears that world agriculture sustains average losses (in terms of monetary value) of around 16\% annually as a result of plant diseases. This overall average conceals instances of good news; with disease loss in the 1 to $2 \%$ percent range as well as bad news of a season of unusually heavy pest incidence which might involve losses in the 30 to $40 \%$ region. Among crops, the total global potential loss due to all pests varied from about $50 \%$ in wheat to more than $80 \%$ in cotton production. Other estimated actual losses are $26-29 \%$ for soybean, wheat and cotton, and 31, 37 and $40 \%$ for maize, rice and potatoes, respectively. Overall, weeds produced the highest potential loss (34\%), with animal pests and pathogens each causing about half that loss (Oerke, 2006).

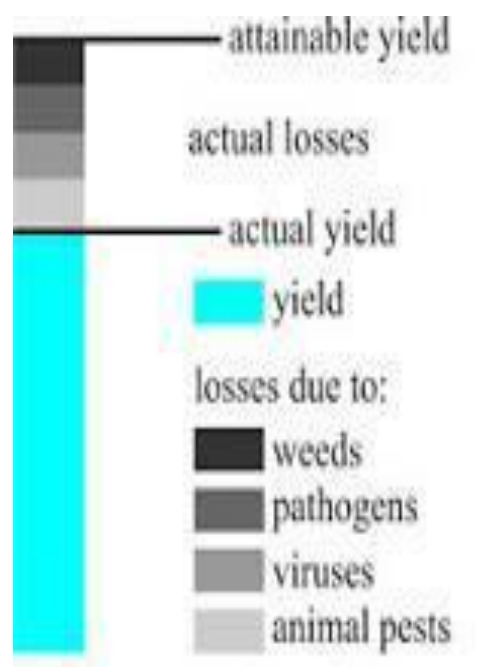

current situation
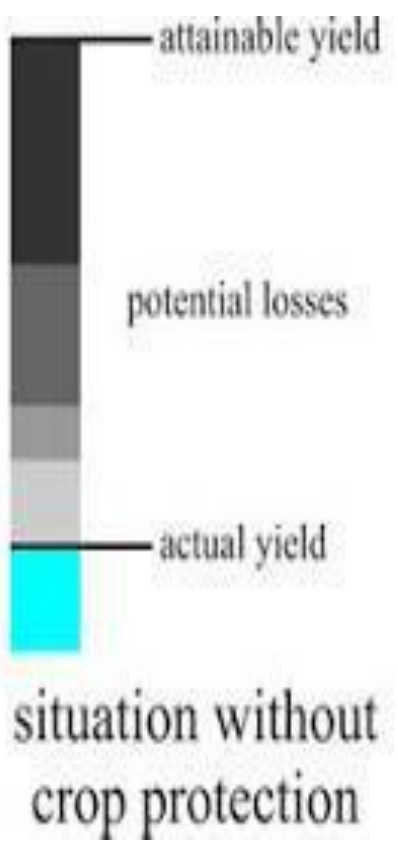

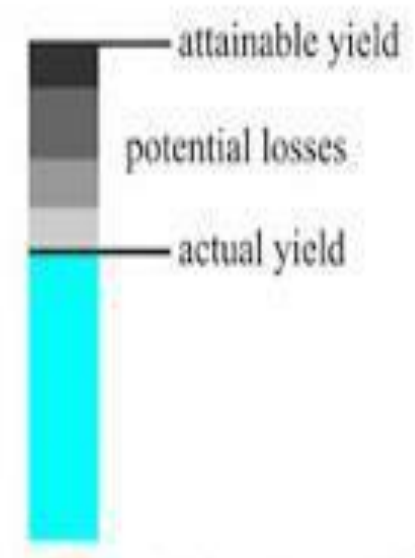

situation without pesticides but with good husbandry

Figure-3: Typical crop losses and yield levels estimated with and without various protection regimes. The value of crop protection practices (shown at left as current situation) can be calculated as the percentage of potential losses prevented by all the crop protection measures that are employed(compare with center panel).In contrast, the impact of pesticide use on crop productivity (right hand panel)takes into account consequential changes in the agricultural system. 
Table 1.1

Some examples of common fungal diseases of vegetable crops are provided in the table below with some typical symptoms.

\begin{tabular}{|c|c|c|c|}
\hline $\begin{array}{l}\text { Fungal } \\
\text { disease }\end{array}$ & $\begin{array}{l}\text { Factors } \\
\text { conducive to } \\
\text { spread }\end{array}$ & Crops affected & Symptoms \\
\hline $\begin{array}{l}\text { White blister/White } \\
\text { rust (Albugo candida) }\end{array}$ & $\begin{array}{l}\text { Optimum conditions for } \\
\text { disease development are } \\
\text { 3-4 hours in mild } \\
\text { temperatures }(6-24 ? \mathrm{C}) \text {. }\end{array}$ & $\begin{array}{c}\text { Brassicas (including Asian } \\
\text { leafy brassicas). }\end{array}$ & $\begin{array}{c}\text { White blisters and } \\
\text { swellings on leaves and } \\
\text { heads of affected } \\
\text { plants; blisters consist } \\
\text { of masses of white dust- } \\
\text { like spores; up to } 100 \% \\
\text { losses have been } \\
\text { reported. }\end{array}$ \\
\hline $\begin{array}{l}\text { Downy mildews } \\
\text { (individual species } \\
\text { damage particular crop } \\
\text { families) }\end{array}$ & $\begin{array}{l}\text { High humidity, leaf } \\
\text { wetness and cool to } \\
\text { mild temperatures }(10- \\
\left.16^{\circ} \mathrm{C}\right) \text {. }\end{array}$ & $\begin{array}{l}\text { Wide host range including } \\
\text { onions; peas; lettuce; celery; } \\
\text { spinach; kale; herbs; } \\
\text { cucurbits; brassicas; Asian } \\
\text { leafy brassicas. }\end{array}$ & $\begin{array}{c}\text { Symptoms usually } \\
\text { begin with yellowish } \\
\text { leaf spots which then } \\
\text { turn brown; downy } \\
\text { growth appears on } \\
\text { underside of leaves. }\end{array}$ \\
\hline $\begin{array}{l}\text { Powdery mildews } \\
\text { (some species are } \\
\text { restricted to particular } \\
\text { crops or crop families) }\end{array}$ & $\begin{array}{l}\text { Moderate temperatures } \\
(20-25 ? \mathrm{C}) ; \text { relatively } \\
\text { dry conditions (unlike } \\
\text { downy mildews). }\end{array}$ & $\begin{array}{l}\text { Wide host range and very } \\
\text { common, especially in } \\
\text { greenhouse crops: } \\
\text { cucumber; melons; } \\
\text { pumpkin; zucchini;parsnip; } \\
\text { beetroot; potato; herbs; } \\
\text { peas; bitter melon;tomato; } \\
\text { capsicum; Brussels sprouts; } \\
\text { cabbage; swedes. }\end{array}$ & $\begin{array}{c}\text { Small, white, powdery } \\
\text { patches on most above- } \\
\text { ground surfaces; } \\
\text { usually observed first } \\
\text { on undersides of leaves } \\
\text { but eventually cover } \\
\text { both surfaces; affected } \\
\text { leaves become yellow, } \\
\text { then brown and papery } \\
\text { and die. }\end{array}$ \\
\hline $\begin{array}{c}\text { Clubroot } \\
\text { (Plasmodiophora } \\
\text { brassicae) }\end{array}$ & $\begin{array}{l}\text { Warm weather; acidic } \\
\text { soil (pH less than 7); } \\
\text { high soil moisture. }\end{array}$ & $\begin{array}{c}\text { Brassicas (including Asian } \\
\text { leafy brassicas). }\end{array}$ & $\begin{array}{l}\text { Plants are yellow and } \\
\text { stunted and may wilt in } \\
\text { hotter parts of the day; } \\
\text { large malformed } \\
\text { 'clubbed' roots which } \\
\text { prevent the uptake of } \\
\text { water and nutrients, } \\
\text { reducing the potential } \\
\text { yield of the crop. }\end{array}$ \\
\hline Pythium species & $\begin{array}{l}\text { Cold, wet soil } \\
\text { conditions; they enter } \\
\text { untreated water } \\
\text { supplies; water supplies } \\
\text { for irrigation and } \\
\text { hydroponics should be } \\
\text { tested regularly. }\end{array}$ & $\begin{array}{l}\text { Many vegetable crops in } \\
\text { including cucurbits; } \\
\text { brassicas; lettuce. }\end{array}$ & $\begin{array}{l}\text { May kill seedlings, } \\
\text { which die before they } \\
\text { emerge or soon after } \\
\text { emergence; plant } \\
\text { collapse. }\end{array}$ \\
\hline
\end{tabular}




\begin{tabular}{|c|c|c|c|}
\hline $\begin{array}{l}\text { Sclerotinia rots }(S . \\
\text { sclerotiorum and } S . \\
\text { minor } \text { - a range of } \\
\text { common names are } \\
\text { used }\end{array}$ & $\begin{array}{l}\text { Windy, cool, humid } \\
\text { weather; wet soil; } \\
\text { survival structures } \\
\text { known as sclerotia } \\
\text { remain viable in soil for } \\
\text { long periods (10-15 } \\
\text { years). }\end{array}$ & Most vegetable crops. & $\begin{array}{l}\text { Water-soaked rotting of } \\
\text { stems, leaves, and } \\
\text { sometimes fruit; } \\
\text { followed by a fluffy, } \\
\text { white and cottony } \\
\text { fungal growth which } \\
\text { contain hard black } \\
\text { pebble-like sclerotia. }\end{array}$ \\
\hline $\begin{array}{l}\text { Sclerotium rots } \\
(\text { Sclerotium } \\
\text { rolfsii and } S \text {. } \\
\text { cepivorum) }\end{array}$ & $\begin{array}{l}\text { S. rolfsii- Warm, moist } \\
\text { conditions. } S \text {. } \\
\text { cepivorum - } \\
\text { Development is } \\
\text { favoured by cool soil } \\
\text { conditions (14-19?C) } \\
\text { and low moisture. }\end{array}$ & $\begin{array}{l}\text { S. rolfsii - Wide host range } \\
\text { including: beans; beets; } \\
\text { carrot; potato; tomato; } \\
\text { capsicum; cucurbits. } S \text {. } \\
\text { cepivorum - only affects } \\
\text { onions, garlic and related } \\
\text { Alliums (shallots; spring } \\
\text { onions; leeks). }\end{array}$ & $\begin{array}{l}\text { S. rolfsii - Lower stem } \\
\text { and root rots; coarse } \\
\text { threads of white fungal } \\
\text { growth surround the } \\
\text { diseased areas; small } \\
\text { brown fungal resting } \\
\text { bodies. S. cepivorum- } \\
\text { Yellowing and wilting; } \\
\text { fluffy fungal growth } \\
\text { containing black } \\
\text { sclerotia forms at the } \\
\text { bases of bulbs. }\end{array}$ \\
\hline $\begin{array}{l}\text { Fusarium wilts and } \\
\text { rots (Various Fusarium } \\
\text { species including } F \text {. } \\
\text { solani and } F \text {. } \\
\text { oxysporum) }\end{array}$ & Warm to hot weather. & $\begin{array}{l}\text { Wide host range including: } \\
\text { brassicas; carrots; } \\
\text { cucurbits;onions; spring } \\
\text { onions; potato; tomato; } \\
\text { herbs; peas; beans. }\end{array}$ & $\begin{array}{l}\text { Causes severe root and } \\
\text { crown rots or wilt } \\
\text { diseases by attacking } \\
\text { roots and basal stems; } \\
\text { cucurbit fruit and potato } \\
\text { tubers can be affected } \\
\text { in storage. }\end{array}$ \\
\hline $\begin{array}{c}\text { Botrytis rots - for } \\
\text { example Grey mould } \\
\text { (Botrytis cinerea) }\end{array}$ & Cool, wet weather. & $\begin{array}{l}\text { Celery; lettuce; beans; } \\
\text { brassicas; cucumber; } \\
\text { capsicum; tomato. }\end{array}$ & $\begin{array}{l}\text { Softening of plant } \\
\text { tissues in the presence } \\
\text { of grey fungal growth. }\end{array}$ \\
\hline $\begin{array}{c}\text { Anthracnose } \\
\text { (Colletotrichum } \\
\text { spp. except for in } \\
\text { lettuce - } \\
\text { Microdochium } \\
\text { panattonianum) } \\
\end{array}$ & Cool, wet conditions. & $\begin{array}{c}\text { Wide range of crops } \\
\text { including: lettuce; celery; } \\
\text { beans; cucurbits; tomato, } \\
\text { capsicum; potato; globe } \\
\text { artichoke. }\end{array}$ & $\begin{array}{l}\text { Typical symptoms } \\
\text { begin with sunken and } \\
\text { water-soaked spots } \\
\text { appearing on leaves, } \\
\text { stems and/or fruit. }\end{array}$ \\
\hline $\begin{array}{c}\text { Rhizoctonia rots } \\
\text { (Rhizoctonia solani) - } \\
\text { range of common } \\
\text { names, e.g. Bottom rot } \\
\text { (lettuce) and Wire stem } \\
\text { (Brassicas) }\end{array}$ & $\begin{array}{l}\text { Warm, humid weather; } \\
\text { can survive for long } \\
\text { periods in the soil in the } \\
\text { absence of a host plant. }\end{array}$ & $\begin{array}{l}\text { Wide host range including: } \\
\text { lettuce; potato; } \\
\text { brassicas; beans; peas; } \\
\text { beets; carrots; capsicum; } \\
\text { tomato; cucurbits. }\end{array}$ & $\begin{array}{l}\text { Range of symptoms } \\
\text { depending on the crop } \\
\text { being grown but can } \\
\text { affect roots, leaves, } \\
\text { stems, tubers and fruit; } \\
\text { plants wilt and may } \\
\text { collapse and die. }\end{array}$ \\
\hline $\begin{array}{c}\text { Damping-off (Pythium, } \\
\text { Rhizoctonia, } \\
\text { Phytophthora, } \\
\text { Fusarium or } \\
\text { Aphanomyces) }\end{array}$ & $\begin{array}{l}\text { Occurs under cold, wet } \\
\text { soil conditions; shore } \\
\text { flies and fungus gnats } \\
\text { can spread Pythium and } \\
\text { Fusarium. }\end{array}$ & $\begin{array}{l}\text { Many vegetable crops } \\
\text { including: leafy } \\
\text { vegetables;brassicas; } \\
\text { carrots; beetroot; cucurbits, } \\
\text { eggplant; tomato; coriander; } \\
\text { spring onions; beans }\end{array}$ & $\begin{array}{l}\text { Young seedlings have } \\
\text { necrotic stems or roots; } \\
\text { seedlings die or show a } \\
\text { reduction in growth. }\end{array}$ \\
\hline
\end{tabular}




\begin{tabular}{|c|c|c|c|}
\hline $\begin{array}{c}\text { Cavity spot (Pythium } \\
\text { sulcatum) }\end{array}$ & $\begin{array}{l}\text { Growing carrots after } \\
\text { carrots; acidic soil; not } \\
\text { harvesting carrots as } \\
\text { soon as they reach } \\
\text { marketable size. }\end{array}$ & Carrots. & $\begin{array}{c}\text { Cavity spots are small } \\
\text { elliptical lesions often } \\
\text { surrounded by a yellow } \\
\text { halo. }\end{array}$ \\
\hline $\begin{array}{c}\text { Tuber diseases } \\
\text { (Various species) }\end{array}$ & & Potato and sweetpotato. & $\begin{array}{l}\text { Potato tubers may be } \\
\text { infected with superficial } \\
\text { skin diseases, such as } \\
\text { common scabs, } \\
\text { powdery scab, and } \\
\text { Rhizoctonia. } \\
\text { Sweetpotatoes may be } \\
\text { infected by scurf. }\end{array}$ \\
\hline $\begin{array}{l}\text { Rusts (several species, } \\
\text { e.g. Puccinia sorghi- } \\
\text { sweet corn; Uromyces } \\
\text { appendiculatus - } \\
\text { beans; Puccinia allii- } \\
\text { spring onions). }\end{array}$ & $\begin{array}{l}\text { Wind can spread spores } \\
\text { great distances; } \\
\text { favoured by low } \\
\text { rainfall, } 100 \% \text { relative } \\
\text { humidity and cool to } \\
\text { mild temperatures. }\end{array}$ & $\begin{array}{l}\text { Sweet corn; beans; onions; } \\
\text { spring onions; beets; celery; } \\
\text { silverbeet; endive. }\end{array}$ & $\begin{array}{l}\text { Small, red or reddish- } \\
\text { brown pustules that } \\
\text { form on the underside } \\
\text { of the leaves and } \\
\text { sometimes on the pods } \\
\text { as well; dusty reddish- } \\
\text { brown spores released } \\
\text { from pustules (may be } \\
\text { black in cold weather). }\end{array}$ \\
\hline $\begin{array}{c}\text { Black root rot } \\
\text { (Different species on } \\
\text { different vegetable } \\
\text { crops) }\end{array}$ & $\begin{array}{l}\text { Cool soil temperatures; } \\
\text { high soil moisture. }\end{array}$ & Lettuce; beans; cucurbits. & $\begin{array}{l}\text { Blackening of roots; } \\
\text { stunted plants; plants } \\
\text { may die. }\end{array}$ \\
\hline
\end{tabular}

Ref: Jay, N. (2005); Drenth, A. (2016); Pitt, H. (1997).

\subsection{Aims and objectives}

In this present study, we aimed to isolate fungus from infected vegetables .Our objectives are

to:-

- To collect sample from infected vegetable

- To isolate fungi from collected sample.

- To identify pathogenic fungi on the basis of morphological studies. 


\section{CHAPTER II}

\section{MATERIALS AND METHODS}




\section{Materials and methods}

This study was conducted at the laboratory of Microbiology, Department of Biotechnology and Genetic Engineering, Islamic University Kushtia, Bangladesh.

\subsection{Sample collection}

Samples of (infected) vegetables of onion and potato were collected in the local area of the Kushtia district. The samples were transported to the laboratory of the Islamic University's biotechnology department in separate sterile plastic bags for pathogenic fungal identification.

\subsection{Materials}

\subsubsection{Equipment}

\section{Conical flask}

Petri-dish

Electric weight balance

Measuring cylinder

Distill water

Tissue paper

Foil paper

Marking pen

Autoclave

Incubator

Laminar air flow cabinet

Micropipette

T Tips

Alcohol

\subsubsection{Media}

We used following two media for our experiment:

Nutrient agar (NA)

Potato Dextrose Agar(PDA)

\subsection{Sample processing}

The vegetables were sterilized on the surface by exposing them in $70 \%$ ethyl alcohol for 1 minute (BDH Chemical Ltd poole England) and then into $1 \%$ sodium hypochlorite for 3 minutes and rinsed three times in sterile distilled water. Segments $(3-5 \mathrm{~cm})$ of tissue were cut from the samples with a sterile scalpel and placed in media previously prepared in Petri dishes and incubated at the appropriate temperature for 3-5 days for complete growth of sporulated fungus. 


\subsection{Isolation and identification of fungi}

The fungal colonies that appeared were identified mainly by morphological characteristics

(Barnett and Hunter, 1972). The fungal isolates were purified by subculture transplantation into a new pool using Potar Dextrose Agar (PDA, Difco). Pure isolated fungal strains were identified using fungal identification keys (Dean, R. 2012 and Compaore, F. 2011). 


\section{CHAPTER III RESULTS}




\section{RESULTS}

\subsection{Isolated Fungus}

The two fungi isolates were obtained from the two infected vegetable plants. The isolates were designated as isolates $\mathrm{S}-1$ and isolates $\mathrm{S}-2$.

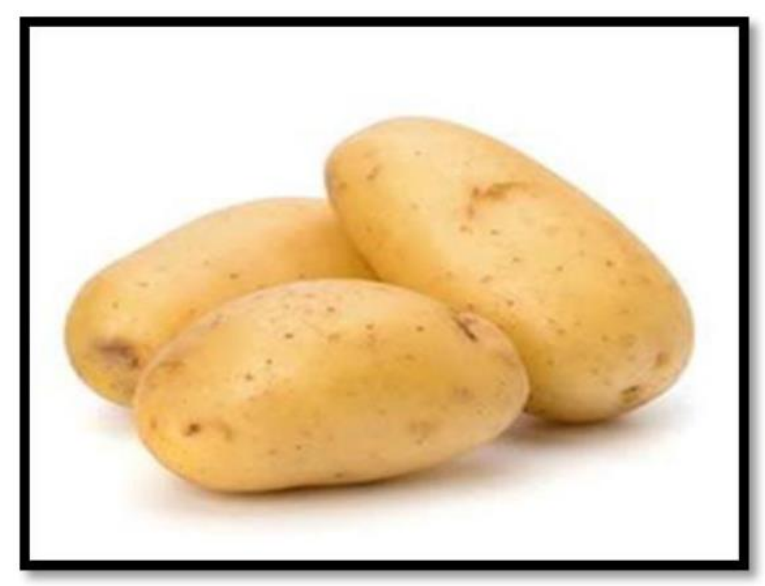

Potato (Solanum tubersum), Healthy

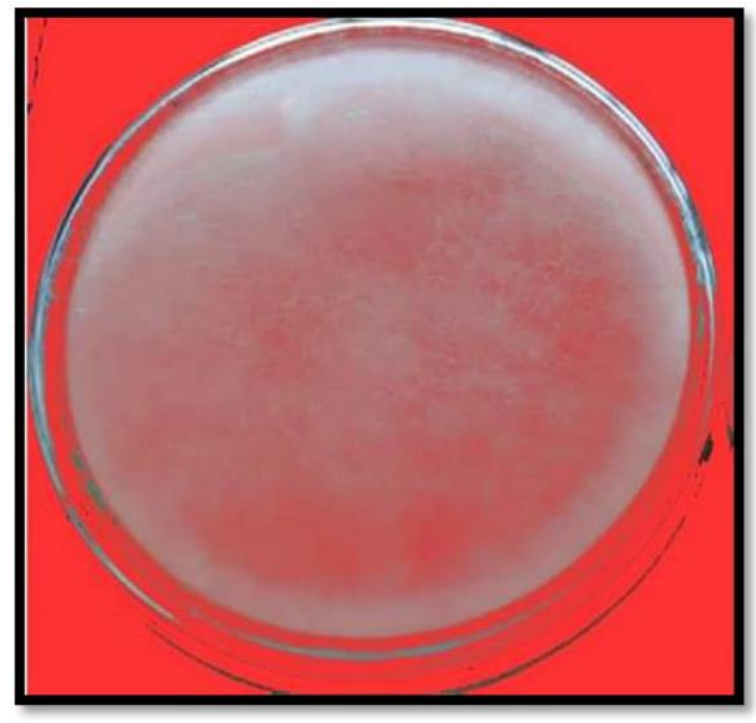

Isolates $\mathrm{S}-1$

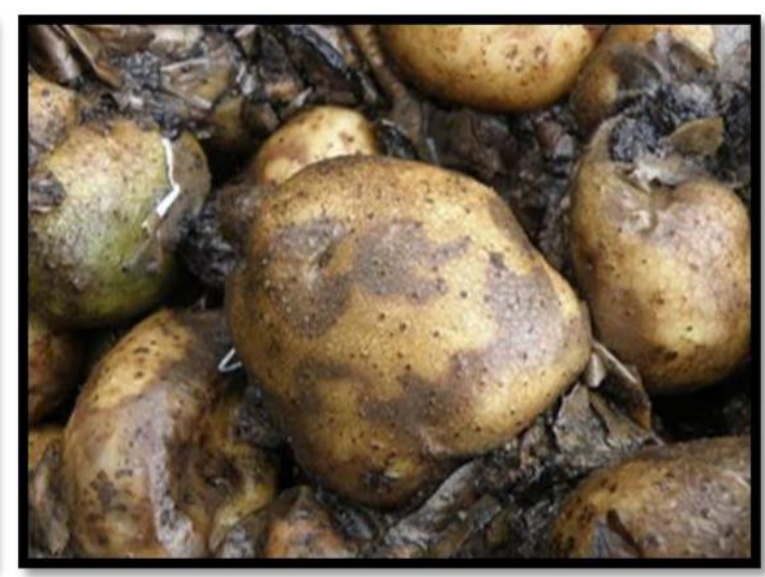

Potato (Solanum tubersum), Infected

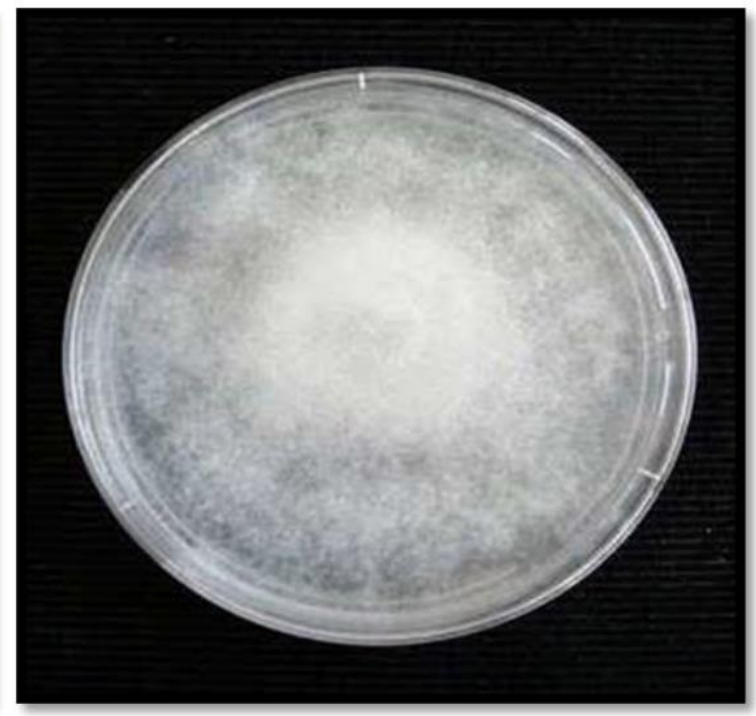

Phytopthora infestans

(Pure culture on PDA media after7 day's incubation at $27 \pm 2^{\circ} \mathrm{C}$ ) (Ref: Dean, R. 2012).

Figure-4: Morphological identification of isolate S-1

As we observed the fungus isolated from infected crops (Solanum tubersum) in our laboratory shows the same morphological characteristics as the Phytopthora infestans (Dean, R. 2012).So primarily confirmed that S-1 is Phytopthora infestans .However, further study is required for further proof. 


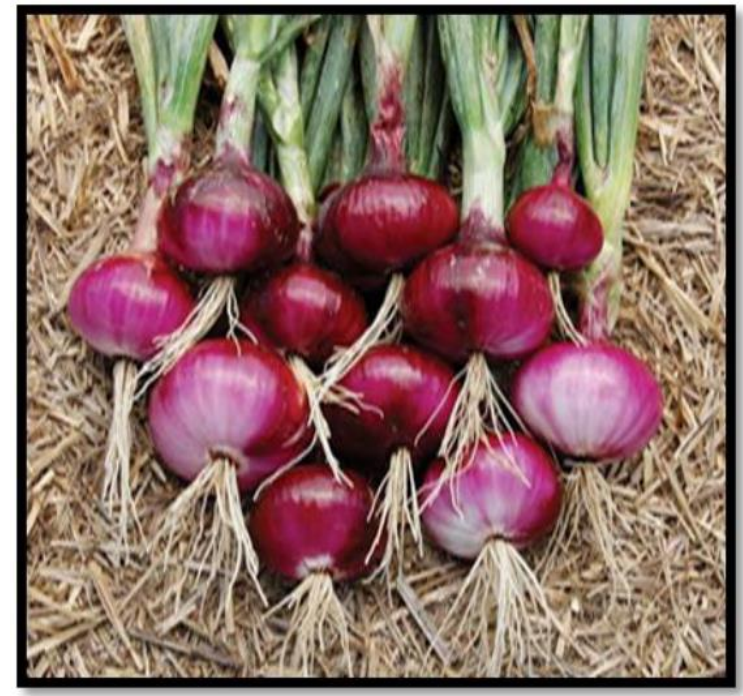

Onion (Allium cepa), Healthy.

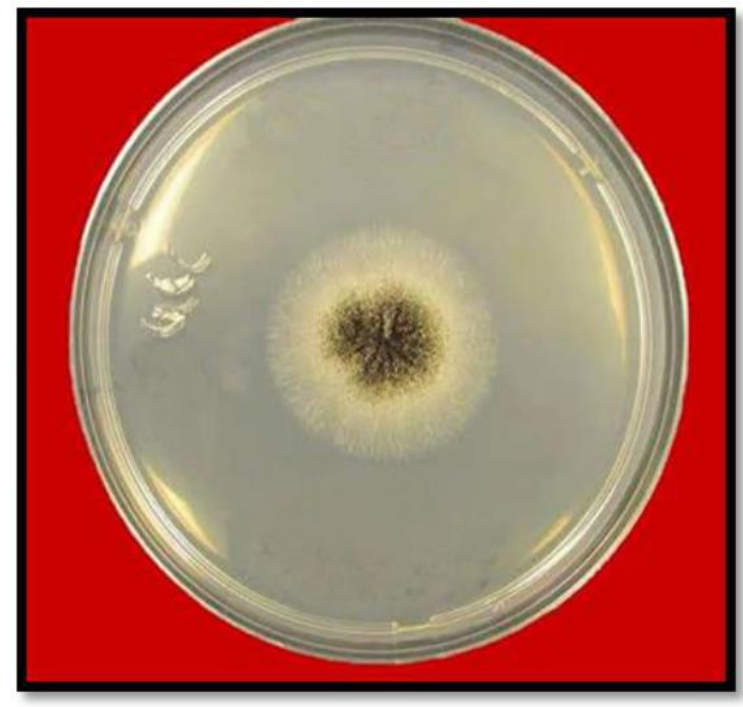

Isolates S-2

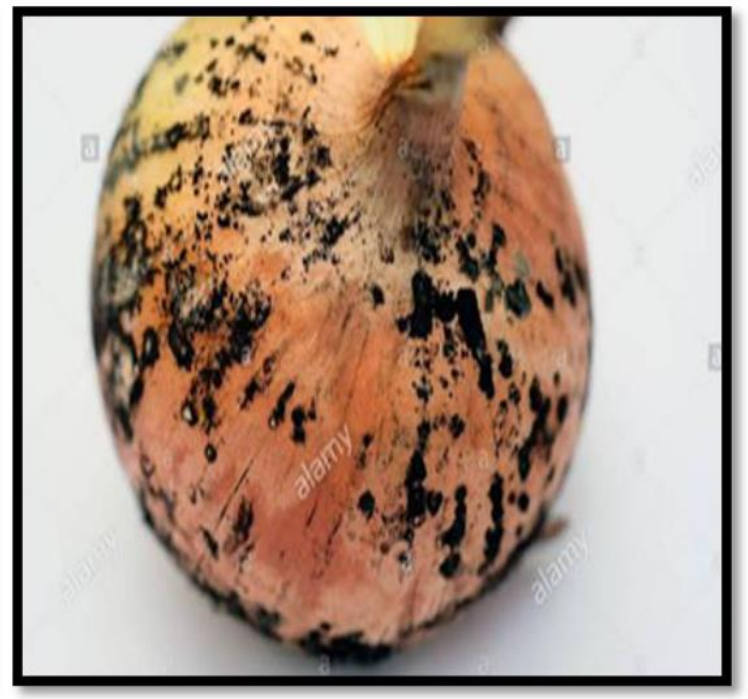

Onion (Allium cepa), Fungal infected.

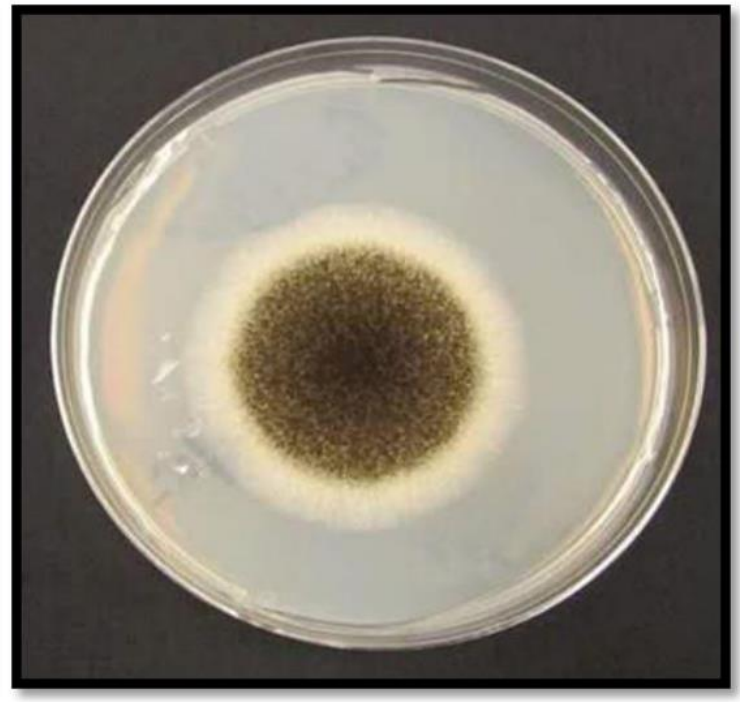

Aspergillus niger

(Pure culture on PDA media after7 day's incubation at $27 \pm 2{ }^{\circ} \mathrm{C}$ ) (Ref: Compaore, F. 2011)

Figure-5: Morphological identification of isolate S-2

As we observed the fungus isolated from infected crops (Allium cepa) in our laboratory shows the same morphological characteristics as the aspergillus niger (Compaore, F. 2011).So primarily confirmed that S-2 is aspergillus niger. However, further study is required for further proof. 
Table 3.1 Isolated fungi with respective host

\begin{tabular}{|l|l|l|l|}
\hline $\begin{array}{c}\text { ISOLATES } \\
\text { NO. }\end{array}$ & NAME OF FUNGI & \multicolumn{1}{|c|}{$\begin{array}{c}\text { SCIENTIFIC } \\
\text { NAME(HOST PLANT) }\end{array}$} & $\begin{array}{c}\text { COMMON NAME OF } \\
\text { HOST PLANT }\end{array}$ \\
\hline S-1. & $\begin{array}{l}\text { Phytopthora } \\
\text { infestans }\end{array}$ & Solanum tubersum & Potato \\
\hline S-2. & Aspergillus niger & Allium cepa & Onion \\
\hline
\end{tabular}

\subsection{Comparison of morphological characteristics of insolated fungi}

Table 3.2 Comparison of morphological characteristics of insolated fungi

\begin{tabular}{|c|c|c|}
\hline Name of fungi & $\begin{array}{c}\text { Morphological features (research } \\
\text { observations) }\end{array}$ & $\begin{array}{c}\text { Morphological features (our } \\
\text { observations) }\end{array}$ \\
\hline Phytopthora infestans & $\begin{array}{l}\text { Produces microscopic, asexual } \\
\text { spores called sporangia. } \\
\text { Sporangia are hyaline (clear), } \\
\text { lemon-shaped and 20-40 um } \\
\text { long. } \\
\checkmark \text { Sporangia are formed on } \\
\text { specialized branches called } \\
\text { sporangiophores. } \\
\checkmark \text { Opaque, white and lemoniform. }\end{array}$ & $\begin{array}{l}\checkmark \text { Observed Sporangia shape } \\
\checkmark \\
\text { Observed Clear sporangia } \\
\checkmark \\
\text { Observed some branches, } \\
\checkmark \text { which formed sporangia. } \\
\text { Observed white colony. }\end{array}$ \\
\hline Aspergillus niger & $\begin{array}{l}\text { Surface colour dark brown to } \\
\text { black spores. } \\
\checkmark \\
\text { Margines are entire. } \\
\text { Rapid growth }\end{array}$ & $\begin{array}{l}\text { After } 7 \text { days of incubation } \\
\text { at } 27^{\circ} \mathrm{C} \text {, they produce } \\
\text { black colonies with wooly } \\
\text { smooth-walled colonies of } \\
\text { conidia. } \\
\text { Observed Rapid growth } \\
\text { and damage vegetables } \\
\text { quickly. }\end{array}$ \\
\hline
\end{tabular}

(Ref: Dean, R. 2012 and Compaore, F. 2011). 


\section{CHAPTER IV DISCUSSION}




\section{Discussion}

Determination of infectious routes of plant pathogens and their mechanisms of infection are of great importance in any disease control program. The findings of this study showed that Aspergillus niger(Onion) and Phytopthora infestans(Potato) were found in vegetables grown in rural area around kushtia. They were found to be associated with spoilage or deterioration of vegetable.

Our finding coincides with the work of Compaore, F. (2011), who also isolated Phytopthora infestans from infected vegetable crops (Solanum tubersum) and Dean, R. (2012) who isolated Aspergillus niger from infected vegetable crops (Allium cepa).

In order to confirm our identified isolates we are interested to study through molecular and biochemical identification and also study the Rhizosphere soil bacteria's anti-fungal activity against these kinds of fungi. Because of the Covid-19 pandemic situation, we are unable to study more in our laboratory. But in the future, to achieve our target, we must run out our research. 


\section{CHPTER V}

CONCLUSION 


\section{CONCLUSION}

In the present study, we are isolated some fungi such as Phytopthora infestans and Aspergillus niger from two types of vegetable Potato (Solanum tubersum) and onion (Allium cepa) by their morphological characteristics. It's found that the yield was decreased due to the infection of this fungi. 


\section{CHAPTER VI REFERENCES}


Adamvoa, M. (2014). Calcium regulates intracellular events in body tissue and plays an important role in muscle construction, enzyme activities, nerve function, blood clotting and regulation. Saudi Journal of Microbial, 51, 665-672.

Adebayo, k. (2012). Eating or drinking contaminated foods or drink can cause food born disease. Journal of Biological Sciences, 9, 265-281.

Aizen, M. (2009). How much does agriculture depend on pollinators? Lessons from long-term trends in crop production. Pakistan journal of Agricultural Science, 12, 265-281.

Alexopoulos, C. (1996). Introductory mycology. Journal of Applied Biological Sciences, 6, 41 48.

Asabra, A. (2002). Fermentation studies on carrot juice processed to table wine. Journal of agricultural and biological science, 9, 373-409.

Barkai-Golan, R. and Paster, N. (2008). Mouldy fruits and vegetables as a source of mycotoxins. European Journal of Scientific Research, 9, 373-409.

Beard, D. (1997). Iron has for long been recognized for its role in maintaining a healthy immune system and disease prevention. Journal of Microbiology, 88, 237-243.

Benson, J. (2002). Microbiological Applications, Laboratory Manual in general microbiology. Saudi Journal of Microbial, 9(13), 911-1918.

Beto, G. (2015). It help ageing and fight with cardiovascular disease. Journal of Biological Sciences, 87, 330-335.

Beuchat, L. (2001). Food born pathogen; human pathogens associated with raw produce and unpasteurized juices and difficulties in decontamination. Journal of industrial microbiology and biotechnology, 27, 104-110.

Bing, H. (2003). Dietary fiber prevention of cancer an observation study. Pakistan journal of 
Agricultural Science, 8, 5-22.

Borth, M. (2009). Spoilage microorganisms can be introduced to the crop on the seed itself, during crop growth in the fields, during harvesting, handling, storage and distribution. Journal of Applied Biological Sciences, 70, 127-137.

Bromenshenk, J. (2010). Iridovirus and microsporidian linked to honey bee colony decline. Journal of Agricultural Technology, 88, 237- 243.

Burkitt, M. (2014). Fiber have important role in improving the digestive system and in general disease prevention. Saudi Journal of Microbial, 6, 41- 46.

Compaore, D. (2011). A.digitatacontains 573000-65300mg/100g fibre. Current Research journal of biological Science, 3(1), 64-72.

Compaore, F. (2011). It is note that toxicity does not occur with vitamin C. Journal of Biological Sciences, 70, 127- 137.

Dean, R. (2012). The Top 10 fungal pathogens in molecular plant pathology. Journal of Microbiology, 13, 705-710.

Drenth, A. (2016). Fungal and oomycete diseases of tropical tree fruit crops. Journal of Pure and Applied Sciences, 20, 69-78.

Fisher, M. (2012). Emerging fungal threats to animal, plant and ecosystem health. European Journal of Scientific Research, 42, 1584-1594.

Hanif, R. (2006). Use of vegetables as nutritional food: role in human health. Journal of agricultural and biological science, 1(1), 217-231.

Hung, M. (2004). The association of fruit and vegetable consumption with the reduction of risk of many disease. Pakistan journal of Agricultural Science, 188, 86-93.

Hurrell, E. (2010). Heme iron which is derived from animal foods and plant tissue and Non heme 
iron which is derived only from plant tissue. American journal of clinical nutrition, 9(5), $14-16$.

Ijato, J. (2010). Allelopathic effect of leaf extract of Azardirachta indica and Chromolaena odorata against post harvest and transit rot of tomato (Lycopersicum esculentum L). Journal of American Science, 6(12), 312-319.

Iqbal, K. (2004).This nutrient which is heat labile is widely distributed in fresh fruits, especially citrus and vegetables. Pakistan journal of nutrition, 3(1), 5-13.

Jay, N. (2005). The primary causative agents of microbial spoilage are bacteria, yeasts and mold. Journal of Microbiology, 13, 705-710.

Jensen, A. (2013). Standard methods for fungal brood disease research. Saudi Journal of Microbial, 61, 289-294.

Jeor, J. (2001).Increased dietary protein intake as weight reduction intervention has been widely reported. African Journal of Agricultural Research, Journal of agricultural and biological science, $15,131-154$.

Jinajali, N. (2017). In wild vegetables A .spinosus contains between 3900-5800mg /100g. African Journal of Agricultural Research, 16, 231-254.

Jinazali, N. (2017). A spinosus which contain between 265-1165mg/100g. African Journal of Agricultural Research, 46, 1843-1852.

Jinazali, N. (2017). All wild vegetables had significantly high levels of Ca for example, A.spinosus had 479-3931mg/100g. African Journal of Agricultural Research, 4, 45-57.

Jinazali, N. (2017).High fibre containing wild vegetables were identified as A.spinosus containing about 2480mg/100g. African Journal of Agricultural Research, 103, 115-134.

Khelenbeck, S. (2013). Wild fruits,especially those whose seeds are consumed have been often 
contain desirable sources of protein. Pakistan journal of Agricultural Science, 168, 653659.

Lynch, C. (1980). Vitamin C has been known to enhance absorption. American journal of clinical Nutrition, 29, 859-67.

Nadler, L. (1997). Magnesium is vital in human nutrition due it's function as a cofactor more than 300 essential enzyme system. Journal of Biological Sciences, 192, 277-283.

Nguyen, C. (1994). The incidence of microorganism in vegetables may be expected to reflect the sanitary quality of the processing. Journal of Applied Biological Sciences, 61, 279-281.

Pitt, H. (1997). Different types of fungi grow on vegetables which can cause a variety of ill effect in human from allergic response to immune suppression and cancer. African Journal of Agricultural Research, 24(9), 285-294.

Radef, L. (2006). Protein functions include their role as enzymes, transport carries, in membranes and as hormones. Journal of Applied Biological Sciences, 10, 4303-4306.

Rivas, A. (1997). Vitamin C plays an important role in human physiology. Body can't synthesized for that it must be exogenously. The journal of biological Chemistry, 272(9), 5814-5820.

Rodrigues, M. (2016). Funding and innovation in diseases of neglected populations: the paradox of cryptococcal meningitis. Journal of Agricultural Technology, 10, 4303-4306.

Rodrigues, M. (2018). Neglected disease, neglected populations: the fight against Cryptococcus and cryptococcosis. European Journal of Scientific Research, 27, 143-149.

Salvin, S. (2013). Dietryfibre as consisting of indigestible carbohydrate and lignin that is intrinsic and intact in plants, Journal of agricultural science, 5(4), 1417-1435.

Sandber, A. (1988). Calcium and animal protein,have been known to inhibit Fe absorption. 
Journal of nutrition, 6, 318-327.

Standlmayr, K. (2013). A.digitatahas been found to contain between 126 and 509mg/100g of vitamin C. Pakistan journal of Agricultural Science, 19, 163-169.

Standlmayr, R. (2013).Meat and vegetables such as spinach are contain high level of iron. Journal of Pure and Applied Sciences, 25, 443-449.

Standlmayr, R. (2013). The current literature search indicates that B.aegyptiacacontains about 44 $\mathrm{mg} / 100 \mathrm{~g}$ of Mg. Journal of agricultural and biological science, 14, 63-69.

Stein, K. (2017). Bee pollination increases yield quantity and quality of cash crops in Burkina Faso, West Africa. Journal of Biological Sciences, 6, 43-52.

Whiting, T. (2010). Insufficient Calcium in the diet has been linked to osteoporosis and bone fraction in adults. African Journal of Agricultural Research, 8, 89-98.

Wu, C. (2016). Amino acid required for the synthesis of body protein and other nitrogen containing compounds. Saudi Journal of Microbial, 7, 39-40. 
CHEPTER VII APPENDICES

Page | 35 


\subsection{Appendices}

List of Culture Media

1. Nutrient Agar (NA)

\begin{tabular}{|l|l|l|}
\hline Nutrient agar & Peptone & $-5.0 \mathrm{gm}$ \\
& Beef extract & $-1.5 \mathrm{gm}$ \\
& Yeast extract & $-1.5 \mathrm{gm}$ \\
& Sodium chloride & $-5.0 \mathrm{gm}$ \\
& Agar agar & $-15 \mathrm{gm}$ \\
& Distilled water & $-1000 \mathrm{ml}$ \\
\hline
\end{tabular}

2. Potato Dextrose Agar(PDA)

\begin{tabular}{|l|l|l|}
\hline PDA media & Potato & $-200 \mathrm{gm}$ \\
& Dextrose & $-20 \mathrm{gm}$ \\
& Agar agar & $-20 \mathrm{gm}$ \\
& Distilled water & $-1000 \mathrm{ml}$ \\
\hline
\end{tabular}

